Research Journal of Animal Sciences 14 (1): 1-11, 2020

ISSN: 1993-5269

(C) Medwell Journals, 2020

\title{
Morphometrical Traits and Structural Indices of Malle Cattle Reared in the South Omo Zone of Southwest Ethiopia
}

\author{
${ }^{1}$ Demerew Getaneh, ${ }^{2}$ Sandip Banerjee and ${ }^{2}$ Mestawet Taye \\ ${ }^{1}$ Animal Breeding and Genetics Jinka Agricultural Research Center, Jinka, Ethiopia \\ ${ }^{2}$ Department of Animal and Range Sciences, Facility of Agriculture, \\ Hawassa University, P. O. Box 05, Hawassa, Ethiopia
}

\begin{abstract}
The study was conducted to morphometrically and morphologically characterized Malle cattle using some predefined qualitative and quantitative parameters and to develop some structural indices to access their type and function. Data were collected through field observations and linear measurements of sample cattle. A total of 360 cattle of different ages of were selected randomly from different locations and morphometrical measurements were carried out on it. Qualitative traits were evaluated using non parametric tests. Quantitative traits were analysed using descriptive statistics. The observed coat color patterns of cattle were predominantly plain. Red and white colored animals predominated across both the sexes. The result of morphometrical measurements indicated that Bulls with young age group (4 year age) exert strong significant effect $(p<0.01)$ on Heart Girth (HG), Height at Rump (HR), Height at Withers (HW), Neck Circumference (NC), Muzzle Circumference (MC) and Chest Depth (CD) while in cows with age group 4 significant effect $(p<0.01)$ on heart girth $(\mathrm{HG})$ and muzzle circumference $(\mathrm{MC})$ whereas $(\mathrm{p}<0.05)$ Height at Withers $(\mathrm{HW})$ were observed. Similarly, in age group 5 significance effect $(\mathrm{p}<0.01)$ on Heart Girth $(\mathrm{HG})$, Neck Circumference (NC) and Chest Width $(\mathrm{CW})$ whereas $(\mathrm{p}<0.05)$ Height at Rump $(\mathrm{HR})$ and Height at Wither $(\mathrm{HW})$ were also observed. The weight of the bulls and cows were best assessed using skeletal measurements viz. body length, height at withers and rump, besides chest depth and width. The findings from the structural indices also indicated that the cattle were well balanced and body length and height were more or less proportional. It was conclude that, along with other managerial improvement, the productive aptitude of the cattle through morphometry can provides relevant information to guide and enhance their productive performance.
\end{abstract}

Key words: Ethiopia, Malle cattle, morphometrical traits, South Omo, structural indices

\section{INTRODUCTION}

Ethiopia has one of the largest livestock resources in Africa with a national herd estimated to be 59.5 million of cattle (CSA., 2014). The cattle in the country are adapted to varying agro ecologies from the highlands of the country (primarily under mixed livestock farming system) to, the lowlands (where they are raised under extensive/ transhumance/nomadic farming system (FAO., 2018). Cattle adapted to a particular agro climate usually can perform better provided the basic amenities related to the management are made available to them, understanding the agro climate also provides an insight of the realistic developments that can be achieved through crossbreeding programs (Berhane, 2017).

Morphometrical traits provide an insight about the genotypes themselves and as most of the skeletal traits are moderately to highly heritable (Mantovani et al., 2010). Thus, assessment of the skeletal traits helps in understanding the adaptability of the animals to their agro climate (Archana et al., 2017). The traits (other than skeletal parameters) viz. chest girth, neck circumference, canon circumference are closely correlated with the body weight of the animals (Cerqueira et al., 2013; Lukuyu et al., 2016). Hence, such traits can serve as predictors for the body weight of the animals. The qualitative traits are those which are usually correlated with the adaptation of the animals and hence are indicative of the agro climate where the animals are acclimatized (Archana et al., 2017).

"Structural indices" on the other hand are the combinations of several linear measurements or morphometrical measurement which collate with the type and function of a particular breed (Maciejowski and Zieba, 1982). Indices offer accurate estimation of an animal's conformation when compared to individual measurements alone (Salako, 2006). Structural indices take into account some genetically correlated phenotypic traits and these indices provide measures for understanding the type and function for which the genotype was developed (Alderson, 1999; Banerjee et al., 2014). The cattle reared in South Omo Zone are known to

Corresponding Author: Demerew Getaneh, Animal Breeding and Genetics Jinka Agricultural Research Center, Jinka, Ethiopia 
be one of the small East African zebu (Terefe et al., 2010). These indigenous types of cattle are yet to be studied in detail and neither have they been characterized phenotypically using structural index parameters. This study was conducted with the objectives of to characterize cattle morphologically and morphometrically using both qualitative and quantitative parameters and to develop some structural indices, so as to access the type and function of the indigenous cattle in the study area.

\section{MATERIALS AND METHODS}

Description of study area: The study was conducted in Malle district which is one of the eight districts situated in South Omo Zone of Southern Ethiopia. The district covers an area of $1432 \mathrm{~km}^{2}$. The population density of the district is very sparse with an estimate of 66 persons per $\mathrm{km}^{2}$. The district has 23 rural kebeles (villages) and 1 urban kebele. The altitude of the district ranges between 600-1500 masl. The study area is situated between $5.08^{0} \mathrm{~N}-6.01^{0} \mathrm{~N}$ latitudinal and $36.3^{\circ} \mathrm{E}-37^{0} \mathrm{E}$ longitudinally. It had comprised $40 \%$ mid-altitude which ranging from $1000-1400$ masl $l$ and whereas $60 \%$ is lowlands which has been ranging from the 605-999 masl. The mean annual rainfall is ranging from $800-1200 \mathrm{~mm}$ with annual temperature has lain between $18-35^{\circ} \mathrm{C}$.

Site selection and sampling techniques: The identification of cattle owners and study site were selected purposively because of they were known to have a reasonably high density of cattle populations. A total of 360 adult cattle ( 120 bulls and 240 cows) of different ages were selected randomly from different locations of study areas for the phenotype survey and morphometrical measurements. A total of 120 cattle owners were selected randomly and interviewed by the researcher. The respondents those who owned atleast 5 adult cattle and at least 5 years experience in rearing them and willing to participate in the program were purposively identified and from the identified cattle rearers $30 \%$ of them were randomly selected from participant.

The cows and bulls those were free from physical defects were selected and it was ensured that the cows were not pregnant beyond two months (was taken by asking the owners of the cattle), this was done to avoid baiseness in morphometry due to pregancy. Care was taken to avoid animals which are emaciated or over conditioned as they were considered as off layers. The morphometry data were assessed using self devised equipments and according to the methods suggested by Maciejowski and Zieba (1982). The body weight of the animals were taken from their chest girth using tape measurements which was specifically developed for zebu cattle.
Assessment of qualitative and quantitative traits: Data on qualitative (morphological characters) and quantitative (morphometric measurements) were collected and recorded on the format adopted from the standard description list developed by FAO. (2012). A total of 16 qualitative characteristic viz. coat color and pattern, horn presence and color separately for male and female, horn shape and orientation, hair length, ear shape and orientation, hump size, head profile and tail length were recorded based on subjective visual observation. Similarly, 15 quantitative traits/parameters/ such as Body Length (BL), Height at Withers (HW), Heart Girth (HG), Horn Length (HL), Ear Length (EL), Tail Length (TL), Height at Rump (HR), Muzzle Circumference (MC), Pelvic Width (PW), HC, Chest Width (CW), Chest Depth (CD), Hip Width (HiW), Neck Length (NL) and Neck Circumference (NC) were measured and recorded using measuring tape and measuring stick. Every experimental animal was identified by sex, age and location. Age were estimated by examining each animal's teeth as suggested by Pace and Wakeman. The Height at Wither (HW), Chest Width (CW), Chest Depth (CD), Hip Width (HiW) and Height at Rump (HR) measurements were taken using the measuring plastic tape marked in centimeter $(\mathrm{cm})$ and a special measuring stick. A graduated measuring stick modified with sliding wooden caliber to it sliding by hand vertically up and down to record height while the animals were measured their body parts in standing position (with the correct posture in a straight-line) on four legs make a rectangle with head maintained in an upright position as described by Goe et al. (2001). On the other hand, Ear Length (EL), Muzzle Circumference (MC), Pelvic Width (PW), Horn Length (HL), Tail Length (TL) and Heart Girth (HG) measurements were taken using a flexible measuring tailor's tape. The measurements were taken at early in the morning to avoid the effect of feeding and watering on the animal's size and conformation. The structural indices were calculated according to the methods suggested by Banerjee et al. (2014), Alderson, (1999) and Salako (2006).

Data management and statistical analysis: Quantitative and qualitative variables measured and collected from field through survey and morphometric measurements were summarized and described by descriptive statistics using Statistical Package for Social Sciences (SPSS 14.0 for windows, release 14.0, 2005). The qualitative traits were accessed using non parametric methods (Chi square analysis) while the means of the quantitative parameters were accessed using one way ANOVA and the significant means were compared by using Duncan's Multiple Range Test, values were considered significant at $\mathrm{p}<0.05$. The effect of location and sex on linear size measurements was analyzed using the following linear model. 
Res. J. Anim. Sci., 141 (1): 1-11, 2020

$$
Y_{i j}=u+a_{i}+b_{j}+c_{k}+e_{i j}
$$

Where:

$\mathrm{Y}_{\mathrm{ij}}$ : Observation value due to ith agro ecology

jth : Sex and kth age within a sex

$\mathrm{u}$ : Overall mean

$\mathrm{a}_{\mathrm{i}}$ : Effect of ith agro ecology on the parameters studied

$b_{j}$ : Effect of jth sex (j; $1=$ heifers/cows, $2=$ steers/bulls) on the qualitative and quantitative parameters

$c_{k}$ : Effect of age within a sex

$\mathrm{e}_{\mathrm{ij}}$ : Residual random effect error associated with the (ij)th observation

\section{RESULTS AND DISCUSSION}

Morphological characteristics of Malle cattle: The results pertaining to the qualitative traits of the Malle cattle reared in the studied areas show (Table 1) that (irrespective of sex) most of the cattle had plain followed by patchy and spotted color patterns. The predominantly the coat colors of the cattle were red and white. Besides the same a minuscule number of cattle too had grey, black, fawn and roan coat colors. The coat color variations $(\mathrm{p}<0.05)$ were also observed across the agro ecologies but the trend was more or less similar. Majority cattle are horned with brown and white horn colors. The

Table 1: Morphological characters of the bulls and cows as observed across study areas (\%)

\begin{tabular}{|c|c|c|c|c|c|c|c|c|}
\hline \multirow[b]{2}{*}{ Characters } & \multicolumn{4}{|l|}{ Male } & \multicolumn{4}{|l|}{ Female } \\
\hline & Midland & Lowland & Overall & $\mathrm{X}^{2}$ & Midland & Lowland & Overall & $\mathrm{X}^{2}$ \\
\hline Coat color pattern & & & & 0.19 & & & & $0.01^{*}$ \\
\hline Plain & 70.7 & 74.2 & 72.5 & & 82.8 & 72.9 & 77.9 & \\
\hline Patchy & 25.9 & 14.5 & 20.0 & & 12.3 & 10.2 & 11.3 & \\
\hline Spotted & 3.4 & 9.7 & 6.7 & & 4.9 & 16.9 & 10.8 & \\
\hline Body hair coat color & & & & 0.22 & & & & 0.09 \\
\hline black & 6.9 & 6.5 & 6.7 & & 1.6 & 3.4 & 2.5 & \\
\hline Dark & 5.2 & 3.2 & 4.2 & & 1.6 & 2.5 & 2.1 & \\
\hline Red & 36.2 & 50.0 & 43.3 & & 46.7 & 39.0 & 42.9 & \\
\hline White & 24.1 & 12.9 & 18.3 & & 21.3 & 15.3 & 18.3 & \\
\hline Fawn & 17.2 & 11.3 & 14.2 & & 13.1 & 20.3 & 16.7 & \\
\hline Grey & 10.3 & 9.7 & 10.0 & & 14.8 & 12.7 & 13.8 & \\
\hline Roan & 0.0 & 6.5 & 3.3 & & 0.8 & 6.8 & 3.8 & \\
\hline Presence of horn & & & & 0.08 & & & & 0.10 \\
\hline Present & 91.4 & 98.4 & 95.0 & & 95.1 & 98.3 & 96.7 & \\
\hline Absent & 8.6 & 1.6 & 5.0 & & 4.9 & 0.9 & 2.9 & \\
\hline Horn colour & & & & 0.59 & & & & 0.15 \\
\hline Black & 15.8 & 9.7 & 12.6 & & 13.9 & 13.7 & 13.8 & \\
\hline Brown & 70.2 & 74.2 & 72.3 & & 77.9 & 70.1 & 74.1 & \\
\hline White & 14.0 & 16.1 & 15.1 & & 8.2 & 16.2 & 12.1 & \\
\hline Horn orientation & & & & $0.00^{* *}$ & & & & $0.00^{* *}$ \\
\hline Tips pointing laterally & 19.0 & 1.6 & 10.0 & & 12.3 & 0.0 & 6.3 & \\
\hline Upward & 46.6 & 79.0 & 63.3 & & 52.5 & 60.7 & 56.5 & \\
\hline Downward & 1.7 & 0.0 & 0.8 & & 1.6 & 0.0 & 0.8 & \\
\hline Forward & 31.0 & 17.7 & 24.2 & & 32.8 & 38.5 & 35.6 & \\
\hline Backward & 1.7 & 1.6 & 1.7 & & 0.8 & 0.9 & 0.8 & \\
\hline Horn shape & & & & 0.28 & & & & $0.02^{*}$ \\
\hline Straight & 17.2 & 9.7 & 13.3 & & 14.8 & 4.2 & 9.6 & \\
\hline Curved & 77.6 & 90.3 & 84.2 & & 82.0 & 94.9 & 88.3 & \\
\hline Lyre shape & 1.7 & 0.0 & 0.8 & & 0.8 & 0.0 & 0.4 & \\
\hline Loose shape & 1.7 & 0.0 & 0.8 & & 0.8 & 0.8 & 0.8 & \\
\hline Polled & 1.7 & 0.0 & 0.8 & & 1.6 & 0.0 & 0.8 & \\
\hline Hair length & & & & $0.00^{* *}$ & & & & $0.00^{* *}$ \\
\hline Short & 60.3 & 93.5 & 77.5 & & 80.3 & 94.9 & 87.5 & \\
\hline Medium & 39.7 & 4.8 & 21.7 & & 18.9 & 2.5 & 10.8 & \\
\hline Long & 0.0 & 1.6 & 0.8 & & 0.8 & 2.5 & 1.7 & \\
\hline Ear orientation & & & & 0.08 & & & & 0.13 \\
\hline Erect & 27.6 & 16.1 & 21.7 & & 11.5 & 11.0 & 11.3 & \\
\hline Lateral & 65.5 & 82.3 & 74.2 & & 86.9 & 82.2 & 84.6 & \\
\hline Drooping & 6.9 & 1.6 & 4.2 & & 1.6 & 6.8 & 4.2 & \\
\hline Ear shape & & & & 0.44 & & & & 0.24 \\
\hline Rounded & 13.8 & 11.3 & 12.5 & & 9.8 & 13.6 & 11.7 & \\
\hline Straight-edge & 86.2 & 88.7 & 87.5 & & 90.2 & 86.4 & 88.3 & \\
\hline Hump size & & & & $0.01^{*}$ & & & & $0.04^{*}$ \\
\hline Absent & 0.0 & 0.0 & 0.0 & & 4.9 & 5.1 & 5.0 & \\
\hline Small & 36.2 & 58.1 & 47.5 & & 79.5 & 89.0 & 84.2 & \\
\hline Medium & 55.2 & 29.0 & 41.7 & & 14.8 & 4.2 & 9.6 & \\
\hline Large & 8.6 & 12.9 & 10.8 & & 0.8 & 1.7 & 1.3 & \\
\hline
\end{tabular}


Res. J. Anim. Sci., 141 (1): 1-11, 2020

Table 1: Continue

\begin{tabular}{|c|c|c|c|c|c|c|c|c|}
\hline \multirow[b]{2}{*}{ Characters } & \multicolumn{4}{|l|}{ Male } & \multicolumn{4}{|l|}{ Female } \\
\hline & Midland & Lowland & Overall & $\mathrm{X}^{2}$ & Midland & Lowland & Overall & $\mathrm{X}^{2}$ \\
\hline Head profile & & & & $0.01^{*}$ & & & & 0.06 \\
\hline Straight & 67.2 & 87.1 & 77.5 & & 73.8 & 81.4 & 77.5 & \\
\hline Concave & 13.8 & 1.6 & 7.5 & & 10.7 & 3.4 & 7.1 & \\
\hline Convex & 13.8 & 11.3 & 12.5 & & 15.6 & 13.6 & 14.6 & \\
\hline Ultra-convex & 5.2 & 0 & 2.5 & & 0 & 1.7 & 0.8 & \\
\hline Tail length & & & & $0.00^{* *}$ & & & & 0.12 \\
\hline Short above hocks & 1.8 & 0 & 0.8 & & 0.8 & 0.8 & 0.8 & \\
\hline Medium about hock & 40.4 & 12.9 & 26.1 & & 27 & 16.1 & 21.7 & \\
\hline Long below hocks & 57.9 & 87.1 & 73.1 & & 72.1 & 83.1 & 77.5 & \\
\hline
\end{tabular}

Table 2: Zoometrical measurements (cm) (Mean \pm SE) of steers/bullsin the two agro-ecologies

\begin{tabular}{|c|c|c|c|c|c|c|c|c|c|}
\hline \multirow[b]{3}{*}{ Traits } & \multicolumn{9}{|l|}{ Age groups } \\
\hline & \multicolumn{3}{|c|}{4 years old $($ Mean \pm SE) } & \multicolumn{3}{|c|}{5 years old $($ Mean \pm SE) } & \multicolumn{3}{|c|}{ 6-9 years old (Mean \pm SE) } \\
\hline & Midland & Lowland & Overall & Midland & Lowland & Overall & Midland & Lowland & Overall \\
\hline$\overline{\mathrm{EL}}$ & $17.73 \pm .45$ & $18.00 \pm .60$ & $17.85 \pm .36$ & $18.94 \pm .43$ & $17.42 \pm .89$ & $18.52 \pm .41$ & $18.4 \pm .42$ & $18.69 \pm .24$ & $18.58 \pm .22$ \\
\hline $\mathrm{BL}$ & $116.46 \pm 1.79$ & $120.8 \pm 1.67$ & $118.5 \pm 1.28$ & $119.55 \pm 2.0$ & $121.28 \pm 2.86$ & $120.04 \pm 1.63$ & $115.2 \pm 1.86$ & $118.40 \pm 1.28$ & $117.20 \pm 1.07$ \\
\hline HG & $130 \pm 1.33^{\mathrm{b}}$ & $142.3 \pm 2.9^{\mathrm{a}}$ & $135.67 \pm 1.9$ & $137.72 \pm 2.03$ & $137.85 \pm 3.19$ & $137.76 \pm 1.68$ & $140.72 \pm 1.98$ & $139.14 \pm 1.72$ & $139.73 \pm 1.30$ \\
\hline HL & $26.38 \pm 1.29$ & $32.07 \pm 2.8$ & $29.23 \pm 1.65$ & $24.47 \pm 1.92$ & $21.71 \pm 2.48$ & $23.66 \pm 1.53$ & $27.16 \pm 1.90$ & $26.59 \pm 1.56$ & $26.80 \pm 1.20$ \\
\hline TL & $73.26 \pm 1.79$ & $74.84 \pm 1.96$ & $74.00 \pm 1.30$ & $73.72 \pm 2.19$ & $75.85 \pm 2.5$ & $74.32 \pm 1.71$ & $75.37 \pm 1.5$ & $74.85 \pm 1.20$ & $75.04 \pm .95$ \\
\hline $\mathrm{HiW}$ & $40.93 \pm 1.31$ & $39.84 \pm 1.35$ & $40.42 \pm .93$ & $41.05 \pm .90$ & $38.57 \pm 1.34$ & $40.36 \pm .77$ & $39.60 \pm .94$ & $39.35 \pm 0.71$ & $39.44 \pm .56$ \\
\hline HR & $104.46 \pm 1.4^{\mathrm{b}}$ & $110.84 \pm 1^{\mathrm{a}}$ & $107.42 \pm 1.0$ & $107.27 \pm 1.51$ & $109.28 \pm 1.91$ & $107.84 \pm 1.20$ & $110.2 \pm 1.14$ & $107.97 \pm .98$ & $108.8 \pm .75$ \\
\hline HW & $107.53 \pm 1.5^{\mathrm{b}}$ & $113.9 \pm 1.34^{\mathrm{a}}$ & $110.5 \pm 1.17$ & $110.94 \pm 1.87$ & $111.57 \pm 2.73$ & $111.12 \pm 1.52$ & $114.6 \pm 1.70$ & $111.33 \pm 1.25$ & $112.56 \pm 1.02$ \\
\hline NL & $39.26 \pm 1.22$ & $40.84 \pm .97$ & $40.00 \pm .79$ & $39.22 \pm 1.0$ & $41.28 \pm 1.34$ & $39.80 \pm .82$ & $38.96 \pm 1.32$ & $38.95 \pm .79$ & $38.95 \pm .69$ \\
\hline $\mathrm{HC}$ & $29.66 \pm 1.22$ & $31.38 \pm .80$ & $30.46 \pm .76$ & $30.66 \pm .52$ & $29.85 \pm 1.16$ & $30.44 \pm .49$ & $30.60 \pm .47$ & $30.02 \pm .42$ & $30.23 \pm .31$ \\
\hline NC & $54.26 \pm 3.1^{\mathrm{b}}$ & $70.53 \pm 4.37^{\mathrm{a}}$ & $61.82 \pm 3.0$ & $64.44 \pm 2.36$ & $66.42 \pm 3.88$ & $65.00 \pm 1.98$ & $67.8 \pm 2.5$ & $68.45 \pm 2.16$ & $68.20 \pm 1.65$ \\
\hline MC & $35.66 \pm 1.09^{b}$ & $39.53 \pm 1.38^{\mathrm{a}}$ & $37.46 \pm .93$ & $37.94 \pm .92$ & $37.14 \pm 1.29$ & $37.72 \pm .74$ & $39.84 \pm .69$ & $39.35 \pm .05$ & $39.53 \pm .40$ \\
\hline CD & $51.26 \pm .96^{\mathrm{b}}$ & $57.92 \pm 1.43^{\mathrm{a}}$ & $54.35 \pm 1.04$ & $53.72 \pm 1.19$ & $53.85 \pm 2.19$ & $53.76 \pm 1.03$ & $61.76 \pm 4.14$ & $55.57 \pm .85$ & $57.88 \pm 1.65$ \\
\hline CW & $39.46 \pm 1.47$ & $43.30 \pm 1.28$ & $41.25 \pm 1.03$ & $40.66 \pm 1.01$ & $41.42 \pm 2.62$ & $40.88 \pm 1.00$ & $42.12 \pm .74$ & $41.33 \pm 1.0$ & $41.62 \pm .68$ \\
\hline PW & $33.00 \pm .45$ & $33.23 \pm .78$ & $33.10 \pm .43$ & $33.88 \pm .34^{\mathrm{a}}$ & $21.28 \pm 1.08^{\mathrm{b}}$ & $33.16 \pm .44$ & $32.92 \pm .50$ & $32.04 \pm .43$ & $32.37 \pm .33$ \\
\hline
\end{tabular}

horn shape and orientations too varied among the bulls and cows reared across the two locations. The horns of the cattle were long and wide with curved, straight and lyre horn shape. Their horns were emerged and oriented upward, forward and tips pointing laterally. The horn orientation and hair length were varied $(\mathrm{p}<0.01)$ across location and sexes.

The most common type of hair is sort, smooth and shiny. Majority of the cattle are characterized by lateral ear orientation with very few of them having droopy ears. Most of the cattle had small to large hump size the proportion of which varied $(\mathrm{p}<0.05)$ both across location and sexes. Most of the cattle had straight and convex head profile. Most of them have long tail (below the hocks). The head profile and tail length of the bull varied $(p<0.05)$ across both the locations. The study indicated that most of the bulls and cows have straight facial profile.

Morphometric measurement of Malle cattle: The findings relevant to the morphometrical traits of the Malle cattle population of bulls were similar across the study areas and for the age group studied (Table 2). The variation was higher among the younger bulls when compared to the older counterparts. The study indicated that the Heart Girth (HG), Height at Rump (HR), Height at Withers (HW), Neck Circumference (NC), Muzzle Circumference (MC) and Chest Depth (CD) values were higher $(\mathrm{p}<0.05)$ among the bulls of 4 years of age and reared in the lowlands. Study further indicated that among the bulls from age category 5 the Pelvic Width (PW) was wider $(p<0.05)$ among the bulls raised in the midlands.

The findings indicate that the differences were mostly observed among the cows aged 4 years old (Table 3 ). The findings show that the HG values were higher $(\mathrm{p}<0.05)$ among the cows reared in the lowlands, the trend was also similar for MC and HW. The results also show that the cows aged 5 years old had higher $(\mathrm{p}<0.05)$ values for $\mathrm{HR}$, $\mathrm{HW}$ and CW. The results also show that there were no differences among the morphometrical traits of the cows aged around 6-9 years of age (Fig. 1 and 2). 
Res. J. Anim. Sci., 141 (1): 1-11, 2020

Table 3: Zoometrical measurements $(\mathrm{cm})(\mathrm{Mean} \pm \mathrm{SE})$ of heifers/cowsin the two agro-ecologies

\begin{tabular}{|c|c|c|c|c|c|c|c|c|c|}
\hline \multirow[b]{3}{*}{ Traits } & \multicolumn{9}{|l|}{ Age groups } \\
\hline & \multicolumn{3}{|c|}{4 years $($ Mean $\pm S E)$} & \multicolumn{3}{|c|}{5 years $($ Mean \pm SE) } & \multicolumn{3}{|c|}{ 6-9 years $($ Mean $\pm S E)$} \\
\hline & Midland & Lowland & Overall & Midland & Lowland & Overall & Midland & Lowland & Overall \\
\hline$\overline{\mathrm{EL}}$ & $18.6 \pm .31$ & $18.5 \pm .25$ & $18.55 \pm .19$ & $18.48 \pm .28$ & $18.33 \pm .39$ & $18.42 \pm .23$ & $18.6 \pm .25$ & $18.46 \pm .24$ & $18.54 \pm .17$ \\
\hline BL & $114.3 \pm 1.03$ & $116.1 \pm 1.22$ & $115.4 \pm .84$ & $113.78 \pm 2.13$ & $118.09 \pm 1.87$ & $115.49 \pm 1.5$ & $114.5 \pm .97$ & $115.76 \pm 1.2$ & $115.12 \pm .77$ \\
\hline HG & $129.6 \pm 1.19^{\mathrm{b}}$ & $134.1 \pm .9^{\mathrm{a}}$ & $132.3 \pm .77$ & $128.18 \pm 1.14^{\mathrm{b}}$ & $136.66 \pm 1.91^{\mathrm{a}}$ & $131.54 \pm 1.16$ & $132.22 \pm 1.19$ & $135.47 \pm 1.36$ & $133.72 \pm .9$ \\
\hline HL & $27.88 \pm 2.21$ & $32.80 \pm 1.60$ & $30.95 \pm 1.31$ & $30.87 \pm 2.29$ & $27.09 \pm 1.97$ & $29.34 \pm 1.58$ & $27.01 \pm 1.38$ & $30.72 \pm 1.8$ & $28.73 \pm 1.12$ \\
\hline TL & $74.22 \pm 1.16$ & $74.34 \pm 1.23$ & $74.29 \pm .86$ & $72.21 \pm 1.27$ & $73.33 \pm 1.71$ & $72.66 \pm 1.01$ & $73.74 \pm .85$ & $73.47 \pm 1.24$ & $73.61 \pm .73$ \\
\hline HiW & $40.00 \pm .79$ & $38.78 \pm .62$ & $39.27 \pm .49$ & $37.90 \pm 0.58$ & $39.61 \pm 1.11$ & $38.58 \pm 0.57$ & $38.64 \pm .54$ & $39.60 \pm .48$ & $39.09 \pm .37$ \\
\hline HR & $104.03 \pm .85$ & $106.02 \pm .97$ & $105.22 \pm .68$ & $103.53 \pm .73^{\mathrm{b}}$ & $106.52 \pm 1.27^{\mathrm{a}}$ & $104.71 \pm 0.69$ & $104.13 \pm .99$ & $104.75 \pm .94$ & $104.41 \pm .68$ \\
\hline HW & $104.16 \pm 1.24^{\mathrm{b}}$ & $107.47 \pm .9^{\mathrm{a}}$ & $106.14 \pm .76$ & $102.0 \pm 1.46^{\mathrm{b}}$ & $108.80 \pm 1.37^{\mathrm{a}}$ & $104.69 \pm 1.12$ & $104.94 \pm 1.12$ & $106.35 \pm 1.24$ & $105.6 \pm .83$ \\
\hline NL & $40.06 \pm .88$ & $39.39 \pm .51$ & $39.66 \pm .46$ & $40.25 \pm .99$ & $40.38 \pm .59$ & $40.30 \pm .64$ & $38.66 \pm .69$ & $38.56 \pm .58$ & $38.61 \pm .45$ \\
\hline $\mathrm{HC}$ & $29.09 \pm .45$ & $28.10 \pm .32$ & $28.50 \pm .27$ & $28.96 \pm .50$ & $29.80 \pm .55$ & $29.30 \pm .37$ & $28.22 \pm .23$ & $29.03 \pm .40$ & $28.60 \pm .22$ \\
\hline NC & $56.51 \pm 1.60$ & $59.39 \pm 1.13$ & $58.23 \pm .94$ & $55.21 \pm 1.61^{\mathrm{b}}$ & $65.95 \pm 1.65^{\mathrm{a}}$ & $59.47 \pm 1.37$ & $57.83 \pm .90^{\mathrm{b}}$ & $61.50 \pm 1.12^{\mathrm{a}}$ & $59.53 \pm .73$ \\
\hline MC & $35.22 \pm .65^{\mathrm{b}}$ & $38.23 \pm .55^{\mathrm{a}}$ & $37.02 \pm .45$ & $36.93 \pm .77$ & $36.57 \pm .77$ & $36.79 \pm .55$ & $36.35 \pm .78$ & $38.29 \pm .75$ & $37.25 \pm .55$ \\
\hline CD & $52.45 \pm .60$ & $53.56 \pm .88$ & $53.11 \pm .58$ & $51.21 \pm 1.04$ & $52.57 \pm 1.36$ & $51.75 \pm .82$ & $53.44 \pm .50$ & $54.21 \pm .71$ & $53.80 \pm .42$ \\
\hline $\mathrm{CW}$ & $39.83 \pm 1.23$ & $38.67 \pm .84$ & $39.14 \pm .70$ & $36.78 \pm .9^{\mathrm{b}}$ & $43.19 \pm 1.79^{\mathrm{a}}$ & $39.32 \pm .99$ & $39.03 \pm .74$ & $39.39 \pm 1.20$ & $39.20 \pm .68$ \\
\hline PW & $33.03 \pm .65$ & $32.97 \pm .38$ & $33.00 \pm .34$ & $31.93 \pm .49$ & $32.33 \pm .45$ & $32.09 \pm .35$ & $32.81 \pm .24$ & $32.66 \pm .32$ & $32.74 \pm .19$ \\
\hline
\end{tabular}
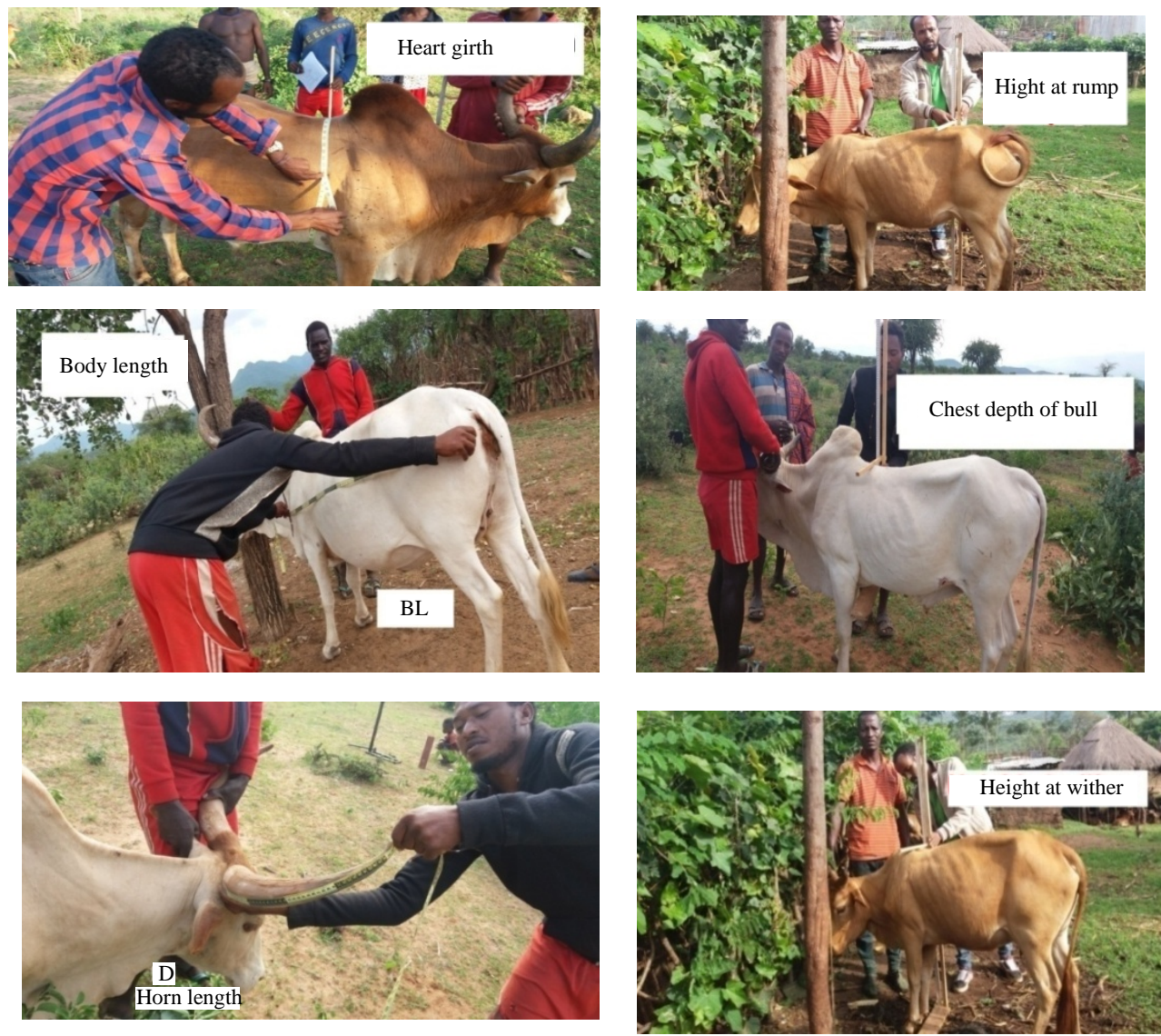

Fig. 1: Measurement of some morphometric traits in Malle cattle

Structural and functional indices of Malle cattle: The structural indices of bulls didn't vary significantly among the bulls reared across the two agro ecologies (Table 4). The structural indices of the cows had higher 
Res. J. Anim. Sci., 141 (1): 1-11, 2020
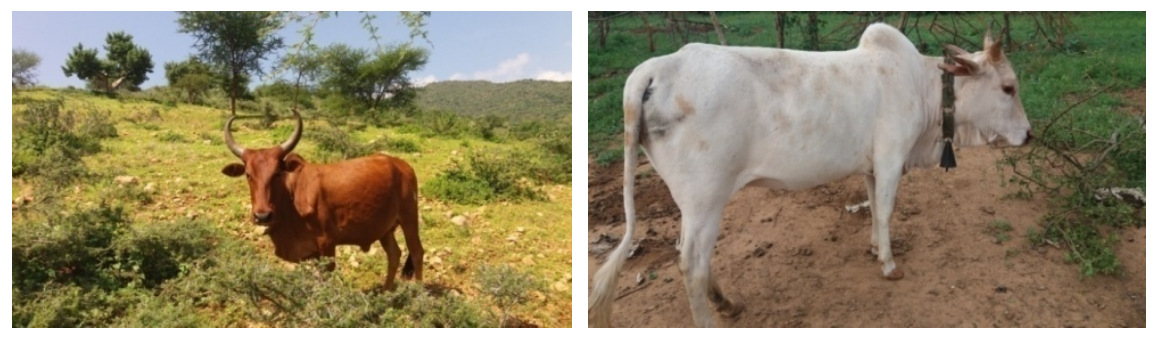

Fig. 2: Typical feature of Malle cow (left) and bull (right) within its natural production environment

Table 4: Structural indices of Malle steers/bulls reared across the studied locations

\begin{tabular}{llll}
\hline Indices & Midland & Lowland & Overall \\
\hline WI & $257.5 \pm 10.24$ & $260.82 \pm 7.45$ & $259.22 \pm 6.24$ \\
HI & $95.82 \pm 0.99$ & $94.02 \pm 0.74$ & $94.89 \pm 0.61$ \\
BI & $85.48 \pm 0.78$ & $85.60 \pm 0.60$ & $85.54 \pm 0.49$ \\
HS & $3.84 \pm 0.58$ & $3.18 \pm 0.60$ & $3.50 \pm 0.42$ \\
LI & $1.05 \pm 0.01$ & $1.07 \pm 0.01$ & $1.06 \pm 0.01$ \\
WS & $1.00 \pm 0.02$ & $0.96 \pm 0.02$ & $0.98 \pm 0.01$ \\
DI & $0.51 \pm 0.02$ & $0.50 \pm 0.01$ & $0.50 \pm 0.01$ \\
FLI & $55.10 \pm 1.86$ & $56.03 \pm 0.79$ & $55.58 \pm 0.98$ \\
TD & $1.23 \pm 0.01$ & $1.25 \pm 0.01$ & $1.24 \pm 0.01$ \\
BRI & $1.04 \pm 0.01$ & $1.03 \pm 0.01$ & $1.03 \pm 0.00$ \\
PI & $95.82 \pm 0.99$ & $94.02 \pm 0.74$ & $94.89 \pm 0.61$ \\
OII & $96.71 \pm 0.48$ & $97.31 \pm 0.52$ & $97.02 \pm 0.35$ \\
\hline WI & &
\end{tabular}

WI = Weight Index; HI = Height Index; BI = Body Index; HS = Height Slope; LI = Length Index; WS = Width Slope; DI = Depth Index; FLI = Foreleg Length Index; TD = Thoracic Development; BRI = Body Ratio Index; PI = Proportionality Index; OII = Over Increase Index; midland $(\mathrm{N}=60)$ and lowland $(\mathrm{N}=60)$

Table 5: Structural indices of Malle heifers/cows reared across the studied locations

\begin{tabular}{llll}
\hline Indices & Midland & Lowland & Overall \\
\hline WI & $222.49 \pm 3.61^{\mathrm{b}}$ & $236.59 \pm 4.63^{\mathrm{a}}$ & $229.42 \pm 2.95$ \\
HI & $91.18 \pm 0.62$ & $92.46 \pm 0.64$ & $91.81 \pm 0.45$ \\
BI & $87.81 \pm 0.68$ & $86.21 \pm 0.57$ & $87.03 \pm 0.44$ \\
HS & $0.02 \pm 0.51^{\mathrm{b}}$ & $1.67 \pm 0.46^{\mathrm{a}}$ & $0.83 \pm 0.35$ \\
LI & $1.10 \pm 0.01$ & $1.09 \pm 0.01$ & $1.10 \pm 0.01$ \\
WS & $1.02 \pm 0.01$ & $1.01 \pm 0.02$ & $1.02 \pm 0.01$ \\
DI & $0.51 \pm 0.00$ & $0.50 \pm 0.01$ & $0.50 \pm 0.00$ \\
FLI & $51.37 \pm 0.73^{\mathrm{b}}$ & $53.56 \pm 0.81^{\mathrm{a}}$ & $52.45 \pm 0.55$ \\
TD & $1.26 \pm 0.01$ & $1.26 \pm 0.01$ & $1.26 \pm 0.01$ \\
BRI & $1.0 \pm 0.01^{\mathrm{b}}$ & $1.02 \pm 0.00^{\mathrm{a}}$ & $1.01 \pm 0.00$ \\
PI & $91.18 \pm 0.62$ & $92.46 \pm 0.64$ & $91.81 \pm 0.45$ \\
OII & $100.24 \pm 0.49^{\mathrm{a}}$ & $98.6 \pm 0.42^{\mathrm{b}}$ & $99.44 \pm 0.35$ \\
\hline
\end{tabular}

$\mathrm{a}, \mathrm{b}(\mathrm{p}<0.05)$ results between the two agro-ecologies significantly different; WI = Weight Index; HI = Height Index; BI = Body Index; HS = Height Slope; LI = Length Index; WS = Width Slope; DI = Depth Index; FLI = Foreleg Length Index; TD = Thoracic development; BRI = Body Ratio Index; PI = Proportionality Index; OII = Over Increase Index; midland $(\mathrm{N}=60)$ and lowland $(\mathrm{N}=60)$

values $(\mathrm{p}<0.05)$ for Weight Index (WI), Height Slope (HS), Foreleg Length Index (FLI), Body Ratio Index (BRI), Over Increase Index (OII) (Table 5).

Prediction of body weight using linear regression equations: The results of the regression analysis of the assessment of the body weight of the bull are presented in Table 6 . The findings show that the body weight of the cattle aged 4 years and reared in the midlands are best assessed with their Body Length (BL) and Horn Length (HL). While, those aged 5 years are best assessed using Height at Rump (HR), Muzzle Circumference (MC) followed by Height at Withers (HW) and Body Length (BL). Furthermore, the bulls aged 6-9 years can be best assessed using their Body Length (BL) and Muzzle Circumference (MC). The bulls raised in the lowlands and aged 4 years are best assessed using the their Chest Depth (CD) while body weight of the bulls aged 5 years are best assessed using their Height at Rump (HR) and Hock/canon Circumference (HC). The body weight of the bulls aged 6-9 years and raised in the lowlands were best assessed using their Body Length (BL), Chest Depth (CD) and Chest Width (CW).

The findings from Table 7, pertaining to the assessment of body weight of the cows reared in the midlands and aged 4 years indicate that the trait is best assessed using Height at Wither (HW) while Chest Depth (CD) was the best estimator for assessing the body weight of the cows aged 5 years. The weight of the cows aged 6-9 years were best assessed by using Height at Wither (HW), Chest Width (CW) and Neck Circumference (NC). The weight of the cows aged 4 years were best assessed using their Pelvic Width (PW) and Neck Length (NL). The weights of cows aged 5 years were best evaluated from their Height at Withers (HW). While the weight of the cows aged 6-9 years were best assessed using Height at Wither (HW), Pelvic Width (PW), Chest Depth (CD) and Body Length (BL).

Morphological characteristics: The most commonly observed coat color patterns for both sexes were plain, patchy and spotted, respectively. The frequency of the coat color patterns as observed in this study varied from results reported by Terefe et al. (2015) for Mursi cattle, Aman (2018) for Arsi cattle, Tewelde et al. (2017) for Begait cattle, Areb et al. (2017) for Bonga cattle and Kebede et al. (2017) for Gamo Gofa cattle. The differences as observed could be ascribed to the sample population and also the preferences by the respective rearers of the cattle. Red and white coat colors (irrespective of sexes and locations) were predominantly 
Res. J. Anim. Sci., 141 (1): 1-11, 2020

Table 6: Body weight estimation from different morphometrical traits of Malle bulls in the two agro- ecologies

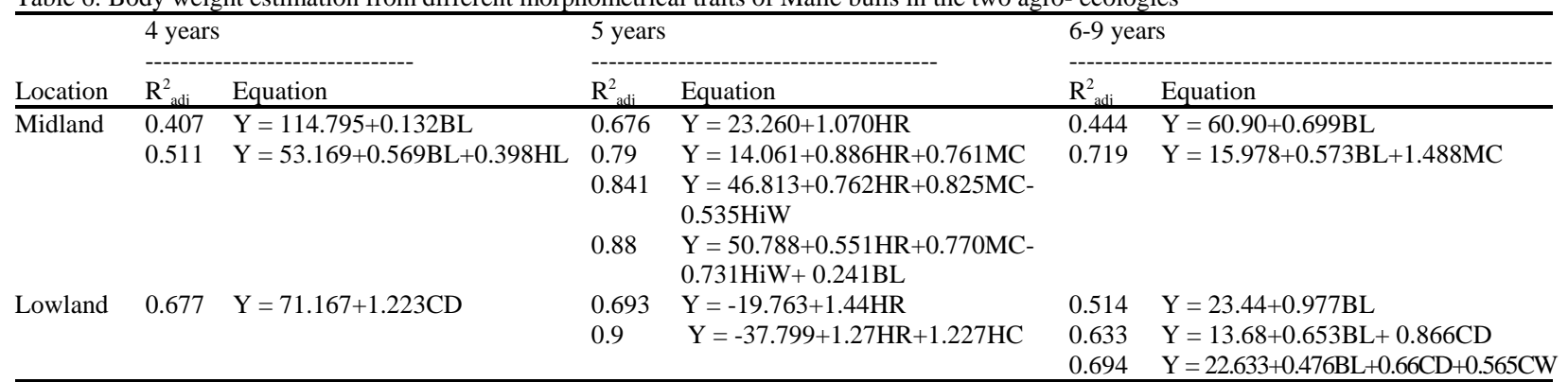

$\mathrm{R}_{\text {adj }}^{2}=$ Adjusted coefficient of determination; BL = Body Length, HL = Horn Length, CD = Chest Depth, HR = Height at Rump, MC = Muzzle Circumference, HiW = Hip Width, HC = Hock Circumference and CW = Chest Width; midland $(\mathrm{N}=60)$ and lowland $(\mathrm{N}=60)$

Table 7: Body weight estimation from different morphometrical traits of Malle cows in the two agro- ecologies

\begin{tabular}{|c|c|c|c|c|c|c|}
\hline \multirow[b]{2}{*}{ Location } & \multicolumn{2}{|c|}{4 years } & \multicolumn{2}{|c|}{5 years } & \multicolumn{2}{|c|}{ 6-9 years } \\
\hline & $\mathrm{R}_{\mathrm{ad}}^{2}$ & Equation & $\mathrm{R}_{\text {adi }}^{2}$ & Equation & $\mathrm{R}_{\mathrm{ad}}^{2}$ & Equation \\
\hline$\overline{\text { Midland }}$ & 0.278 & $\mathrm{Y}=74.81+0.528 \mathrm{HW}$ & 0.27 & $\mathrm{Y}=104.25+0.65 \mathrm{CD}$ & $\begin{array}{l}0.573 \\
0.683 \\
0.73\end{array}$ & $\begin{array}{l}\mathrm{Y}=47.445+0.808 \mathrm{HW} \\
\mathrm{Y}=33.175+0.739 \mathrm{HW}+0.550 \mathrm{CW} \\
\mathrm{Y}=27.148+0.640 \mathrm{HW}+0.487 \mathrm{CW}+0.327 \mathrm{NC}\end{array}$ \\
\hline Lowland & $\begin{array}{l}0.233 \\
0.288\end{array}$ & $\begin{array}{l}\mathrm{Y}=91.80+1.274 \mathrm{PW} \\
\mathrm{Y}=74.45+1.234 \mathrm{PW}+0.475 \mathrm{NL}\end{array}$ & 0.301 & $48.87+0.807 \mathrm{HW}$ & $\begin{array}{l}0.491 \\
0.636 \\
0.706 \\
0.743\end{array}$ & $\begin{array}{l}\mathrm{Y}=48.517+0.815 \mathrm{HW} \\
\mathrm{Y}=6.053+0.664 \mathrm{HW}+1.790 \mathrm{PW} \\
\mathrm{Y}=-5.223+0.579 \mathrm{HW}+1.464 \mathrm{PW}+0.572 \mathrm{CD} \\
\mathrm{Y}=14.501+0.496 \mathrm{HW}+1.061 \mathrm{PW}+0.572 \mathrm{CD}+0.270 \mathrm{BL}\end{array}$ \\
\hline
\end{tabular}

$\mathrm{R}_{\text {adj }}^{2}=$ Adjusted coefficient of determination; HW = Height at Wither, $\mathrm{PW}=$ Pelvic Width, NL = Neck Length, CD = Chest Depth, CW = Chest Width, $\mathrm{NC}=$ Neck Circumference; midland $(\mathrm{N}=60)$ and lowland $(\mathrm{N}=60)$

observed, the white coated cattle are better adapted to the lowlands (Minuye et al., 2018; Terefe et al., 2015). This is because the white coat color can repulse the infra-red radiation better than the dark coated animals (Kubkomawa et al., 2018). The red coated cattle on the other hand survive better in the midlands as the ultra violet radiation in the midlands are better waded off by dark coated animals. The intermediate coat colors may be a resultant of the crosses between the two extreme coat colors. The variable coat color probably helps the breed to adapt the very hostile environment through avoiding effects of radiation and heat stress (Terefe et al., 2015). The variation in coat color depends upon geographical and climatic environment (Seo et al., 2007).

Coat color is an important selection criterion for the bulls and cows in the areas. Black coat color are not preferred culturally, thereby, reducing the market price of such animals (Kubkomawa et al., 2018). Most of the cattle have horns as the trait is correlated with their beauty (Dioli, 2018; Tewelde et al., 2017). The cattle with long horns are able to defend themselves better than polled. This may also be a trait unique for the breed as many of the zebu cattle are horned. The long horns of the cattle are also helpful in digging the soil for minerals locally known as "Bole". The study also indicated that the tails of the cattle are long which is helpful for the cattle to wade off the flies and ecto parasites (Tewelde et al., 2017). The skull/head profile/of the cattle are coffin shaped and straight which indicates that the head is wider near the forehead which tapers down to the muzzle which too is in close accordance with the findings of Aman (2018) and Taye (2005). The hairlength of the cattle (irrespective of both the sexes) are short which correlates with those of the zebu cattle (Tewelde et al., 2017) and shorter hairlength helps in allowing the dissipation of heat as the skin is near to that of the atmosphere (Porto-Neto et al., 2018). The hump is a unique anatomical feature of the zebu cattle and the size of which correlates the ability of the bulls to be used for draft purposes. The medium size of the hump is usually erect and such bulls can be used for draft purposes as the York usually fits properly to such hump (Areb et al., 2017).

\section{Morphometric characteristics}

Ear Length (EL): The morphometrical measurement (irrespective of sexes and age groups) of the Ear Length (EL) of the cattle is similar to those of Mursi (Terefe et al., 2015) and Begait cattle (Gebreyohanes, 2015). But, lower than those of Horro and Ogaden cattle (Getinet et al., 2009). The cattle from the lowlands usually have longer ears as it helps in dissipation of body temperature (Tewelde et al., 2017).

Body Length (BL): The average values for Body Length (BL) of the bulls are similar to the values reported by Getinet et al. (2009) for Ogaden breed. The values for the trait are however lower than those of Mursi breed/bull (Terefe et al., 2015), for Begait cattle/bull (Ftiwi and Tamir, 2015) and for Kereyu bull (Garoma, 2006). The $\mathrm{BL}$ in the present study is however, higher than those for 
Sheko breed (Taye, 2005) and Gamo Gofa cattle (Kebede et al., 2017. The average BL of Malle cows was higher than those of Sheko, Mursi and Gamo Gofa those reported by Taye (2005), Terefe et al. (2015) and Kebede et al. (2017), respectively. The BL is also correlated with the body weight of the cattle (Tewelde et al., 2017). This is because cattle with larger skeletal dimensions fetch higher price when compared to their shorter counterparts (Alsidding et al., 2010). However, such cattle require longer space and also maintenance ration (Cerqueira et al., 2013).

Heart Girth (HG): The average Heart Girth (HG) of Malle cattle has higher values for age group 4 years (irrespective of sex) and have lower value when compared to those of Sheko, Mursi and Gofa cattle/breed reported by Taye (2005), Terefe et al. (2015) and Kebede et al. (2017), respectively. Cattle with wider chest girth usually have higher body weight as the pleural cavity houses many of the vital organs and the development of these organs influence their body weight (Tewelde et al., 2017).

Horn Length (HL): The Horn Length (HL) of the bulls and cows are similar to those reported by Terefe et al. (2015) in Mursi cattle, however, shorter values for the trait too have been reported by Garoma (2006) for Kereyu Cattle. The HL was higher than those reported by Tewelde et al. (2017), Aman (2018) and Worku (2017). The HL is a trait unique for a breed and the trait is genetically determined (Chamberlain, 2017). The presence and absence of horns are influenced by few pairs of genes while their length is polymorphic trait influenced by several pairs of genes (Chamberlain, 2017). Longer horns in one way is advantageous for the animal for defending itself against predators while on the other hand its disadvantageous when it comes to the management point of view as such animals usually are aggressive and can cause physical damage to their handlers and other herd mates. Thus, it's advisable to at least blunt out the pointed ends of the horns so that the animals cannot cause grievous damage to their handlers.

Tail Length (TL): The Tail Length (TL) of the bulls and cows too are in close agreement with the findings of Worku (2017) and Terefe et al. (2015). However, the trait is shorter than those reported by Tewelde et al. (2017), Bekele (2015) and Gebreyohanes (2015). Cattle with longer TL have advantage in the tropical climate as such animal are able to drive away external parasites and flies which can be a cause of irritation to the animals (Tewelde et al., 2017). However, longer tails too have their own disadvantage as they easily get entangled in the thorns and can be easily damaged (Stull et al., 2002). Moreover, many of the predators usually take advantage of long tails to pull down animals (Stull et al., 2002).
Hip width (HiW): The Hip width (HiW) of the bulls as observed in the study are in close agreement with the findings of Worku (2017), bulls with narrow hips usually have slender body and their average body width is also less (Banerjee et al., 2014). The trait is of more important for the cows as narrow hip (pelvis) is correlated with higher incidences of dystocia (Worku, 2017).

Height at Rump (HR): The average values of Height at Rump (HR) of the Malle bulls have higher value (in age group 4) but the values are lower than Horro cattle (Bekele, 2015), Kereyu bull and cow (Garoma, 2006), Shaka cattle (Worku, 2017) and Begait cattle (Tewelde et al., 2017). The higher HR indicates that the hind quarters of the cattle is long and therefore is correlated with the overall height of the cattle (Cerqueira et al., 2013). The height at the rump is an extremely important measure because it is easily measured and because many body measurements will be proportional.

Height at Withers (HW): The average value of Height at Withers (HW) in this study indicated that the values were higher than reported by Taye (2005) for Sheko bulls. But lower than those of Kereyu, Ogaden, Mursi, Gamo Gofa and Begait bull those reported by Garoma (2006), Getinet et al. (2009), Terefe et al. (2015), Kebede et al. (2017) and Ftiwi and Tamir (2015), respectively. The HW as reported in the present study for the cows was similar to those reported by Terefe et al. (2015) for Mursi cows. But lower than Kereyu, Ogaden, Gamo Gofa and Begait cows those reported by Garoma (2006), Getinet et al. (2009), Kebede et al. (2017) and Gebreyohanes (2015), respectively. The trait is of profound importance as HW determines how tall the animals are (Worku, 2017). Tall animals are able to walk for longer distances for grazing purposes and the trait is also correlated with the long fore and hind limbs (Worku, 2017; Cerqueira et al., 2013). The taller the animals are the abdominal cavity of the animals are away from the ground and therefore, the vital organs are further away from the ground thereby, it is also correlated with the adaptation of the animals as a whole (Alsidding et al., 2010). Studies by Mwacharo et al. (2006) have indicated that animals adapted to the hot and humid climate have shorter HW while those adapted to the arid climate with sparse vegetation cover have higher height at withers and longer limbs.

Neck Length (NL): The Neck Length (NL) is a trait which is correlated with the feminity and masculinity in case of mammals (Worku, 2017). The males have thicker and shorter neck while the conversely is true for the females (Bekele, 2015). The average values for neck length for Malle bulls was higher than those reported for 
Res. J. Anim. Sci., 141 (1): 1-11, 2020

Sheko (Taye, 2005) and for Horro bull (Bekele, 2015) but lower than for Begait (Gebreyohanes, 2015) and for Kereyu bull (Garoma, 2006). The neck NL values are also correlated with the development of the cervical vertebrae which is helpful for draught purposes in cattle (Worku, 2017).

Muzzle Circumference (MC): The muzzle is an important part of the facial profile and cattle with wider muzzles usually have more numbers of sweat glands per unit area and therefore are better adapted to the warm climates (Sumena et al., 2010). The muzzle is also an important part of the facial profile as wider muzzle means wider nasal passage and such animals usually have higher endurance capacity (Sumena et al., 2010). The average value of muzzle circumference (irrespective of sex and age group) in this study was lower than for Kereyu (Garoma, 2006) but higher than for Horro cattle (Bekele, 2015).

Chest Depth (CD): The mean value of Chest Depth (CD) obtained in this study are lower than those reported by Getinet et al. (2009) for Ogaden breed of bulls and cows. However, the values as recorded are higher than those reported by Worku (2017) and Aman (2018). The results related to the chest depth and chest width are correlated with the pleural capacity as such animals usually have higher lung capacity and therefore are able to endure the hot climate better (Banerjee et al., 2014). These two traits are also correlated with the chest (heart) girth of the animals and therefore have immense economic importance (Alderson, 1999).

Pelvic Width (PW): The average value of Pelvic Width (PW) is close accordance with those of Bekele (2015) for Horro cattle; Taye (2005) for Sheko breed; Garoma (2006) for Kereyu cattle. However, the finding was lower than report of Tewelde et al. (2017) for Begait cattle and Gebreyohanes (2015) for Begait cattle. The finding was also higher than those of Aman (2018) and Worku (2017). The PW and width of the hip are more or less correlated and the PW correlates with the space between the pelvic girdles (Worku, 2017). The trait is of importance with the cows as wider pelvic space implies lesser chances of dystocia and safer parturition.

Structural indices of Malle cattle: Pertaining to the structural indices of the cattle reared at the studied locations are smaller in size and weight (irrespective of the locations they are raised) which is a breed character and the values as recorded are in close accordance with the findings of Aman (2018) for Arsi cattle breed. The Height Index (HI) as recorded in the study indicate that the cattle are more or less proportional in height at withers and body length which is good for the cattle as such animals tend to suffer less from spinal related problems and the bulls have a good draftablity (Banerjee et al., 2014).

The Body Index (BI) shows that the pleural cavity is well developed among the studied cattle and that the lung capacity of the cattle is well developed for high endurance (Sumena et al., 2010). The values for the Height Slope (HS) indicate that the rear part of the animals (towards the rump) are sloped backwards indicating that the forequarters are longer than those of the hind quarters and such animals are surefooted and can move freely in the mountains and in forests (Alderson, 1999; Cerqueira et al., 2013; Chacon et al., 2011). The results related to the Width Slope (WS) indicate that the hip width and the chest width is more or less similar indicating a rectangular body. However, such animals can have problems of dystocia especially among the cows (Chacon et al., 2011; Worku, 2017). The Chest Depth (CD) of the cows are half of the height at withers indicating that the pleural cavity is well developed and extends well to the knees of the cattle and such animals are good draft animals (Banerjee et al., 2014).

Estimation of body weight: The findings indicate that the body length (BL) of the bulls are best indicators of the assessing body weight of the bulls aged 4 years and 6-9 years of age, this may be because the animals have well developed skeleton and there is enough space for rumen and other allied offal's besides the skeletal tissues the findings are in close accordance with the observations of Ozkaya and Bozkurt (2008) while Height at Rump (HR) is considered as the best indicator of body weight of the bulls which too are in close according to the observations of Alsidding et al. (2010). The findings also indicate that the body weight of the bulls reared in the lowlands is best assessed using chest depth, chest width. The accuracy for estimation of body weight of the cows are quite low which can be due to differences in management of the cows and that the same can be improved by increasing the sample size (Alsidding et al., 2010; Lukuyu et al., 2016). Cows with higher height at withers have longer fore and hind legs thereby higher body weight (Ozkaya and Bozkurt, 2008). It can therefore be concluded that the larger the skeletal frame of the cattle higher is their body weight as the weight of the bones influence the overall weight of the animals.

\section{CONCLUSION}

The findings showed that the Malle cattle type are compact animals having long legs, ears and horns with mostly red and white coat color. These cattle are slender looking animals having light bone shiny and short hairs. The coat color pattern of the cattle varies from plain, patchy or spotted with red, white and/or mixed hair coat 
color with straight skulls. Both sexes' cattle are horned which are long and curved. The structural indices showed that the cattle can trek for long distances and being of compact body are well suitable in grazing around bushes.

\section{RECOMMENDATIONS}

Though the qualitative and quantitative traits are assessed, there is high movement of cattle in the area hence, there are chances of crossbreeding, thus, conservation efforts need to be strengthened. The quantitative traits need to be accessed on a larger population of animals besides using newer methods, i.e., laser guided equipment's, so that, the accuracy is further improved. Based on the results of the morphometical traits, molecular characterization of the cattle population have to be initiated.

\section{ACKNOWLEDGEMENTS}

This study was made possible with funding from Southern Agricultural Research Institute (SARI). Researchers are extremely thankful the SARI and also Jinka Agricultural Research Center for providing logistical support.

\section{REFERENCES}

Alderson, G.L.H., 1999. The development of a system of linear measurements to provide an assessment of type and function of beef cattle. Anim. Genet. Resour. Inform., 25: 45-56.

Alsidding, M.A., S.A. Baker, M.Y. Galal and A.M. Mohammed, 2010. Phenotypic characterization of sudanzebe cattle. Res. J. Anim. Vet. Sci., 5: 10-17.

Aman, G., 2018. Studies on structural, functional traits and traditional breeding practices of Arsi cattle in East Showa and West Arsi Zone of Oromia Reginal State Ethiopia. M.Sc. Thesis, College of Agriculture, Hawassa University, Ethiopia.

Archana, P.R., J. Aleena, P. Prana, M.K. Vidya and P.A. Abdul Niyas et al., 2017. Role of heat shock proteins in livestock adaptation to heat stress. J. Dairy Vet. Anim. Res., Vol. 5. 10.15406/ jdvar.2017.05.00127

Areb, E., T.G. Silase, D.H. Giorgis, C. Reti, B. Zeleke and M. Mamiru, 2017. Phenotypic characterization and production system of Bonga cattle in its production environment of Kaffa Zone, Southwest Ethiopia. Sky J. Agric. Res., 6: 62-72.

Banerjee, S., M. Beyan and H. Bekele, 2014. Some traditional livestock selection criteria as practiced by several indigenous communities of Southern Ethiopia. Anim. Genet. Resour., 54: 153-162.
Bekele, D., 2015. On farm phenotypic characterization of indigenous cattle and their production systems in Bako Tibe and Gobu Sayo Districts of Oromia Region, Ethiopia. M.Sc. Thesis, Haramaya University, Haramaya, Ethiopia.

Berhane, H., 2017. Ethiopian cattle genetic resource and unique characteristics under a rapidly changing production environment-A review. Int. J. Sci. Res. (IJSR), 6: 1959-1968.

CSA., 2014. Federal democratic republic of Ethiopia central statistical agency: Key findings of the 2013/2014 (2006 EC) agricultural sample survey. Central Statistical Agency, Ethiopia.

Cerqueira, J.O.L., J.P.P. Araujo, P.S. Vaz, J. Cantalapiedra and I. Blanco-Penedo et al., 2013. Relationship between zoometric measurements in Hosltein-Fresian cow and cubicle size in dairy farms. Int. J. Morphol., 31: 55-63.

Chacon, E., F. Macedo, F. Velazquez, S. Rezende, E. Pineda and C. McManus, 2011. Morphological measurements and body indices for Cuban Creole goats and their crossbreds. Rev. Bras. Zootec., 40: 1671-1679.

Chamberlain, A., 2017. Identification of horned and polled Bos taurus using a gene test. B.Sc. Thesis, Lincoln University, New Zealand.

Dioli, M., 2018. Nomad aesthetic: Cattle modifications among the Northern Turkana of North West Kenya. Pastoralism, Vol. 8, 10.1186/s13570-017-0110-4

FAO., 2012. Phenotypic characterization of animal genetic resources. FAO Animal Production and Health Guidelines No. 11, Rome, Italy.

FAO., 2018. Africa sustainable livestock Livestock production systems spotlight Cattle sectors in Ethiopia. Food and Agriculture Organization, Rome, Italy.

Ftiwi, M. and B. Tamir, 2015. On-farm phenotypic characterization of indigenous Begait cattle in Western Tigray, Northern Ethiopia. J. Anim. Prod. Adv., 5: 718-732.

Garoma, S., 2006. In-situ phenotypic characterization of Kereyu cattle type in Fentalle district of Oromia region, Ethiopia. M.Sc. Thesis, Haramaya University, Haramaya, Ethiopia.

Gebreyohanes, M.F., 2015. Production system and phenotypic characterization of Begait cattle and effects of supplementation with concentrate feeds on milk yield and composition of Begait cows in Humera ranch, Western Tigray, Ethiopia. Ph.D. Thesis, Adiss Abeba University, Addis Abeba, Ethiopia.

Getinet, M., A. Workineh and P.B. Hegde, 2009. Growth and reproductive performance of Ogaden cattle at Haramaya University, Ethiopia. Ethiop. J. Anim. Prod., 9: 13-38. 
Goe, M.R., J.R. Alldredge and D. Light, 2001. Use of heart girth to predict body weight of working oxen in the Ethiopian highlands. Levest. Prod. Sci., 69: 187-195.

Kebede, H., A. Jimma, A. Getiso and B. Zelke, 2017. Characterization of Gofa Cattle population, production system, production and reproduction performance in Southern Ethiopia. J. Fish. Livest Prod., Vol. 5, No. 5. 10.4172/2332-2608.1000237

Kubkomawa, H.I., 2018. The use of Artificial Insemination (AI) technology in improving milk, beef and reproductive efficiency in tropical Africa: A review. J. Dairy Vet. Sci., Vol. 5, No. 2. 10.19080/JDVS.2018.05.555660

Lukuyu, M.N., J.P. Gibson, D.B. Savage, A.J. Duncan, F.D.N. Mujibi and A.M. Okeyo, 2016. Use of body linear measurements to estimate liveweight of crossbred dairy cattle in smallholder farms in Kenya. SpringerPlus, Vol. 5. 10.1186/ s40064-016-1698-3

Maciejowski, J. and J. Zieba, 1982. Genetics and Animal Breeding: Biological and Genetic Foundations of Animal Breeding Part 1. Elsevier, Amsterdam, Netherlands, ISBN: 9780444996961, Pages: 283.

Mantovani, R., M. Cassandro, B. Contiero, A. Albera and G. Bittante, 2010. Genetic evaluation of type traits in hypertrophic Piemontese cows. J. Anim. Sci., 88: 3504-3512.

Minuye, N., G. Abebe and T. Dessie, 2018. On-farm description and status of Nuer (Abigar) cattle breed in Gambella Regional State, Ethiopia. Int. J. Biodivers. Conserv., 10: 292-302.

Mwacharo, J.M., A.M. Okeyo, G.K. Kamande and J.E.O. Rege, 2006. The small East African shorthorn zebu cows in Kenya. I: Linear body measurements. Trop. Anim. Health Prod., 38: 65-74.

Ozkaya, S. and Y. Bozkurt, 2008. The Relationship of Parameters of Body Measures and Body Weight by Using Digital Image Analysis in Pre-Slaughter Cattle. Arch. Tierzucht Dummerstorf, 51: 120-128.
Porto-Neto, L.R., D.M. Bickhart, A.J. Landaeta-Hernandez, Y.T. Utsunomiya and M. Pagan et al., 2018. Convergent evolution of slick coat in cattle through truncation mutations in the prolactin receptor. Front. Genet., Vol. 9, 10.3389/fgene.2018.00057

Salako, A.E., 2006. Application of morphological indices in the assessment of type and function in sheep. Int. J. Morphol., 24: 13-18.

Seo, K., T.R. Mohanty, T. Choi and I. Hwang, 2007. Biology of epidermal and hair pigmentation in cattle: A mini-review. Vet. Dermatol., 18: 392-400.

Stull, C.L., M.A. Payne, S.S. Berry and P.J. Hullinger, 2002. Evaluation of the scientific justification for tail docking in dairy cattle. J. Am. Vet. Med. Assoc., 220: 1298-1303.

Sumena, K.B., K.M. Lucy, J.J. Chungath, N. Ashok and K.R. Harshan, 2010. Regional histology of the subcutaneous tissue and the sweat glands of large white Yorkshire pigs. Tamilnadu J. Vet. Anim. Sci., 6: 128-135.

Taye, T., 2005. On-farm phenotypic characterization of Sheko breed of cattle and their habitat in Bench Maji Zone, Ethiopia. M.Sc. Thesis, Haramaya University, Haramaya, Ethiopia.

Terefe, E., T. Dessie, A. Haile, W. Mulatu and O. Mwai, 2010. Husbandry and breeding practices of cattle in Mursi and Bodi pastoral communities in Southwest Ethiopia. Afr. J. Agric. Res., 7: 5986-5994.

Terefe, E., T. Dessie, A. Haile, W. Mulatu and O. Mwai, 2015. On-farm phenotypic characterization of Mursi cattle in its production environment in South Omo Zone, Southwest Ethiopia. Anim. Genet. Resourc., 57: 15-24.

Tewelde, G., Y. Sintayehu and B. Sandip, 2017. Some morphometrical, production and reproduction traits of Begait cattle reared in Tigray region of Ethiopia. Wayamba J. Anim. Sci., 9: 1571-1585.

Worku, M., 2017. Assessment of type function and traditional selection practices of indigenous cattle reared in Shaka Zone South West Ethiopia. M.Sc. Thesis, College of Agriculture, Hawassa University, Ethiopa. 